\title{
Agency and the roles of Southern Jordanian Bedouin women on pilgrimage and visiting holy sites
}

$\mathrm{n}$ the Islamic world, numerous shrines shape and define its spiritual landscapes. While some of the shrines are tombs and memorials of major religious and historical figures, a majority of the sites are dedicated to ancestors of the local families and tribes. They function as centres of the religious community, but they also provide a secluded location for private spiritual visits and individual prayers. Women have participated in public rituals also, but it is in the private religious sphere that the women have created a space for independent religious action, connected, and yet separate from their mundane roles.

\section{Introduction}

Apparently my mother-in-law had lost her voice. It had been getting worse since the wedding (all that singing) and she had tried herbal drinks and some pills from another woman without success. I thought she should rest her voice, but she had decided an act of appeasement was called for: a visit to the ancestors Ayal Awwad. She was seven months pregnant, but that apparently was no obstacle. (van Geldermalsen 2009: 86)

This memory, narrated by Marguerite van Geldermalsen, a New Zealander, who married a Bedouin man in 1978 and raised her family in the local community in Petra, offers a glimpse of the common tradition of visiting a holy site to find a resolution for a personal issue. While the memories of the annual pilgrimage and celebrations attended by the whole community abound in people's narratives, it is quite likely, that small, personal visits like the one above were much more common, and probably also more significant in the daily lives of the people. The women who participated in both the private and communal pilgrimages played several roles in these events.

In this paper, I will discuss the active, independent - and even rebellious - participatory or leadership roles of women in the local religious practices, especially pilgrimage. My main questions are: what types of roles have the women performed, and what kind of religious agency do these roles enable? An important issue is also the change that has taken place in recent decades, and how recent fluctuations in the interpretations and implementations of the Islamic tradition have affected women's agency in the context of both local and global pilgrimages.

I will first introduce the theoretical framework, focusing on the work of Mustafa Emirbayer and Ann Mische (1998), which discusses agency as being embedded in the surrounding structure, continuously reconstructed and re-evaluated through the three temporal dimensions: past, present and future. Following a description of the methodology, I will give a brief introduction to the tradition of saints in Islam, and then move on to introduce the region, the holy sites, and traditions related to these sites, focusing on women's participation and their narratives. While a large part of my material is about Jabal Harun, the mountain of Aaron, which is the central shrine in Southern Jordan, I will also introduce other important holy sites known to the tribes. These represent small-scale traditions, rarely known outside the tribe, village or community. Yet, on this local level, these sites have been an uncontested part of the lived religion. The types of pilgrimage documented from the region range from large and annual celebrations, attended by hundreds of people, to small, individual stops at a shrine during the course of the daily routine. 
Subsequently, I will analyse the role of women and their agency on public and private pilgrimages, comparing the practices found here with other regions of the Islamic world (Abu Lughod 1990; Andezian 1997; Cuffel 2005; Hegland 2003; Greenberg 2007; Mernissi 1977), but also paying attention to temporal changes in the structure. I present the pilgrimage to Jabal Harun and other local sites as a tradition deeply embedded in the identity and religious culture of the region, yet at the same time embedded in transnational structures and affected by global fluctuations. ${ }^{1}$

\section{Religion, agency and structure}

Agency is one of the much-debated yet elusive concepts in sociology (Kristiansen 2014; Hitlin and Johnson 2015; Kupari 2016: 29). The main focus of the theoretical discourse has been on the relationship between agency and structure (e.g. Giddens 1984). It is the structure that is often considered to be definitive (Mahmood 2005) and constraining of (Gulati and Srivastava 2012) agency. In feminist studies, structure was originally seen as inherently oppressive towards women, whose only means of showing agency would be through resistance (Mernissi 1977; Abu-Lughod 1990). In the wake of a subsequent approach to agency and structure which has emphasized the dynamic interplay of the two, the traditional view of women's agency has also been contested (Mahmood 2001, 2005; Kupari 2016). Instead of portraying women as a powerless, passive and homogeneous group who are victims of the dominant social structure, the various forms of agency - including the ones that appear to support the structures - need to be recognized and discussed (Teppo 2007: 382; Korteweg 2008; Kupari 2016: 26).

1 Georg Stauth and Samuli Schielke (2008) note how the 'local traditions' of the Islamic world are in fact very unified in structure and form, and portray a number of similar elements. Thus it would be a fallacy to approach them as 'folk', 'popular' or 'local' traditions, as opposed to a 'scholarly' or 'formal' religion. While I use the concept 'local tradition' in this article, it is intended as a reference to the geographic area from which my empirical data originates, and as a definition of the locally known sites within this region, compared to the more nationally and globally oriented structure that has mostly replaced the earlier ones. In general, I consider both forms of religious thought as part of 'lived religion'.
Emirbayer and Mische (1998: 970) present a theory which defines agency as

... the temporally constructed engagement by actors of different structural environments - the temporal-relational contexts of action - which, through the interplay of habit, imagination, and judgment, both reproduces and transforms those structures in interactive response to the problems posed by changing historical situations.

This definition combines elements from various preceding definitions, such as Bourdieu's idea of agency as habitual and repetitive; the goal-seeking element emphasized by rational choice theory, and the idea of agency as deliberation and judgment (Emirbayer and Mische 1998: 963). More than merely action, agency is seen as a dynamic deliberation that takes place in three temporal zones. The iterational dimension focuses on the past, recognizing and selecting traditions, routines and habits that are relevant to the current act. It is the choice of accepted models of action, practices that have been used before, and whose effects are easy to predict, based on earlier experience. These actions provide stability and continuity, and strengthen the relationships between agents, as they can always trust that others will act in the same, predictable way.

The second, projective dimension extends into the future. It is an imaginative distancing from the prevailing structures, containing both future possibilities and narrative reconstructions of the past with a reference to future desires and goals. Such experimentations can also take place in ritual activities, such as a pilgrimage. The third dimension, practicalevaluative, takes place in the present. It is a contextual response to a contingency, based on desired goals and results. The decision may be semi-automatic, based on habits and traditions, or lead to projective executions, as an attempt to change the prevailing condition. The actions may also contain subtle resistance or disguised dissent. Such tactics of resistance are used to sidestep constraining rules (Emirbayer and Mische 1998: 1001; see also Hegland 2003 for the topic of subtle power resistance).

The work of Emirbayer and Mische has been criticized for focusing mainly on intentions and preliminary evaluations, never reaching the point of the taking of action (Porpora 2015: 135). Despite this, the 
authors provide a framework that allows the study of structure as it is in constant interplay with agency, especially with regard to the past, where previous experiences are evaluated in relation to the current situation. Thus, the structure is not seen as purely separate from agency, but being in constant interaction with agency, and as such, being also reshaped by the course of action. Subjects are culturally-constructed beings who sometimes show agency even through subordinate actions, intentionally choosing to comply with, or reinforce, the existing system (Ahearn 2000: 13; Teppo 2007: 382; Svärd 2013; O’Brien 2015). In relation to religious agency, Laura Leming (2007: 73) discusses how individuals simultaneously endorse and uphold the prevailing societal structures and participate in the ongoing, gradual transformation of these same structures, also acting as agents in handing on these practices.

The projective dimension, as defined by Emirbayer and Mische, offers the opportunity to discuss evaluations of the future based on existing structures that are easily ignored in the research, such as aspirations for the life to come, and personal desires to live a good life on the basis of religious tenets. Such evaluations may result in actions that maintain and

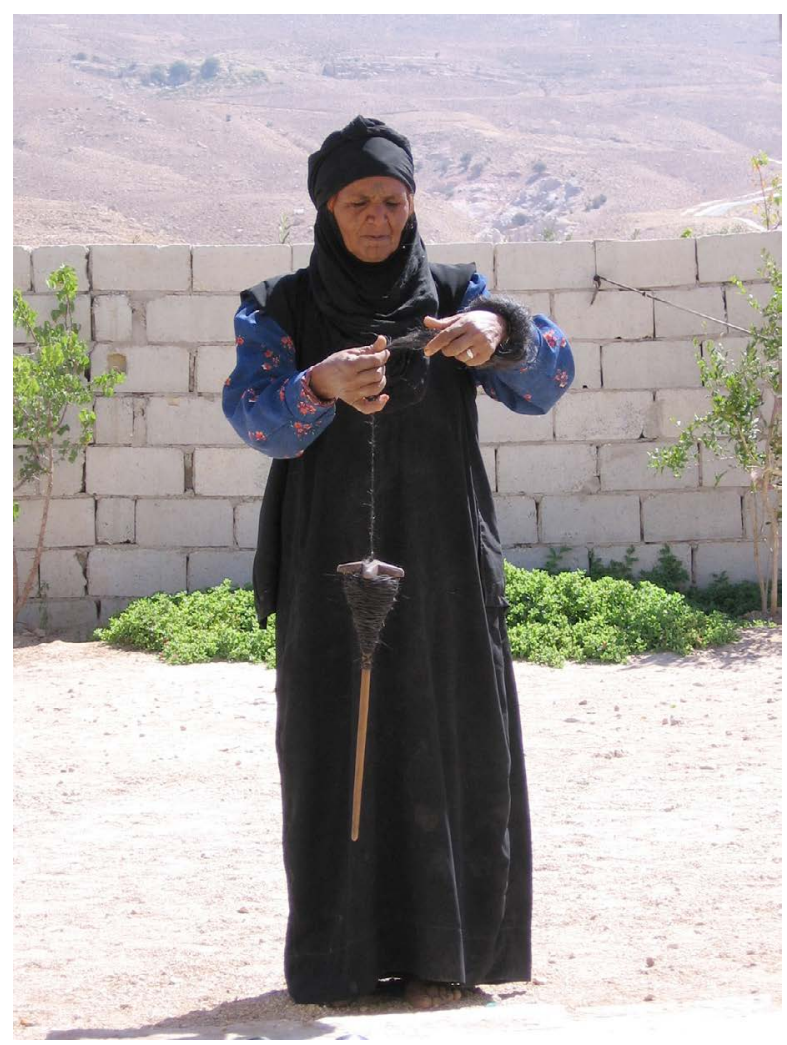

Bedouin woman spinning wool in Baydha. Photo: Päivi Miettunen. support the structure. For Saba Mahmood (2005: 32), this type of behaviour does not constitute any form of agency. Rather, they are activities controlled and produced by the prevailing power structures and authorities. On the other hand, Pierre Bourdieu's definition of any human action as a means to gain status, prestige and power extends to pious and moral actions (Winchester 2008: 1759). However, David Winchester's (2008) study of Muslim converts in Missouri attests to how creating a moral or pious self is not merely a dictation of power structures, but a conscious action. Moreover, he concludes that moral actions should be viewed from a wider perspective than merely arising from a desire to gain status.

This work is an empirical, micro-level study that focuses on women's narratives concerning religious practices and pilgrimage. For Bedouin women, the different stages of life from childhood to puberty, marriage, motherhood and finally, post-menopause, have designated roles and differing modes of agency. I look at these roles as categorizations emanating from the surrounding social structures, from which the framework for agency is drawn. While the orthodoxy and orthopraxy of various religious activities are discussed by the informants, I do not attempt to provide any dogmatic interpretations of the practices described in my work - these are definitions given by the women themselves, all of them also contested.

Following the structuration theory of Anthony Giddens (1984), the structure, represented here by the roles available to women at a designated time and situation, can thus be observed as both an enabler and a constrainer of agency. For example, in the city of Ma'an, young unmarried girls were not allowed to visit the female saint Umm Jadi. On the other hand, in modern Jordanian communities, only women over the age of 40 are allowed to go on a pilgrimage to Mecca without a male guardian. In both cases, the roles are defined by age, which is thus both a constraint, and an enabler for an action.

In short, this study observes roles as structural and social frameworks, and agency as a temporal and situational conscious effort enacted in interaction with societal roles. Historical and social contexts are very relevant in the study of agency, as one must also consider what the subjects think about agency in terms of where agency exists and how the whole reality is being constructed (Teppo 2007:384). Following this, women's agency should be observed in the context of the social, temporal and structural framework 


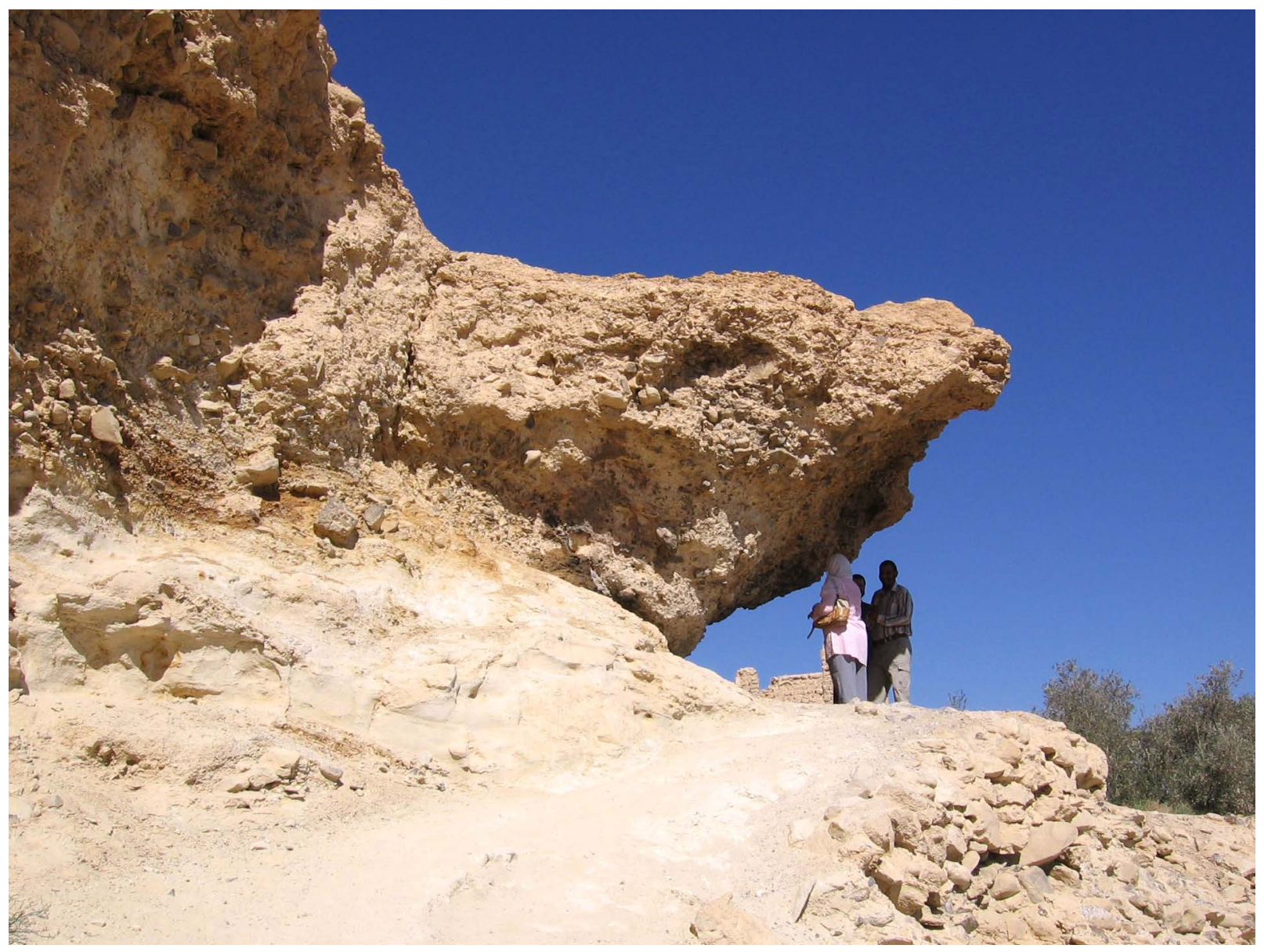

Umm Jadi' in Ma'an. Photo: Päivi Miettunen.

and it should not be reduced to a mere dichotomy of submission to, or resistance against, the structure.

\section{Methodology}

In 2000 I became a member of an archaeological project that was excavating the Byzantine pilgrimage centre located on Jabal Harun, the mountain of Aaron, some 5 kilometres southwest of the ancient city of Petra. During the periods of fieldwork I lived and worked for several weeks at a time on the mountain, near the fourteenth-century Islamic shrine of the Prophet Harun which stands at the very top of the mountain. This gave me an opportunity to observe and interview local workers, visitors and pilgrims on the mountain during my stay. In 2002, 2005 and 2007 I surveyed several holy sites in Southern Jordan, collecting both ethnographic material about the traditions and beliefs, and documenting the material structures of the sites. In the course of this work, I lived for five months with a Bedouin family in 2005, with frequent shorter visits in the years following, remaining involved with the archaeological project until 2008.

The main body of oral narratives originate from my stay with the family. The social circle consisted of a typical extended household: the head of the family with his wife and two of their children (an adult son who was still unmarried, and a widowed daughter with her two children) shared a small concrete house. Their married children all lived nearby and frequently visited the parents. The active social life offered many opportunities for informal discussions and semi-formal interviews. In addition to participating in the daily life of the family, I also made several visits to other regions, including Baydha, Wadi Rum and Wadi Araba. Attending celebrations such as weddings and iftar dinners provided information about larger communal gatherings and social situations.

Material evidence found on holy sites I surveyed, such as ash from burned incense, white cloths and fireplaces, pointed towards recent activity. However, 
despite the periods of participant observation in the family and on Jabal Harun, I was never able to record and observe annual pilgrimages to local holy sites. Observations of individual visits to the sites are also limited to the shrine of Harun - I never met other visitors on any of the other sites. This may be partially due to timing, but more likely the reasons are related to changing attitudes and transformations in religious thinking, often mentioned by the local informants. In recent decades the numbers of visitors and visits to the holy sites have decreased, eventually becoming nearly non-existent. The major body of data therefore comes from oral narratives collected from local informants who have attended the pilgrimage.

This paper revisits the data collected during my $\mathrm{PhD}$ project, and presents a new theoretical and contextual approach to the material, focusing on a topic I only briefly touched upon in my dissertation. Furthermore, the data is supplemented by information collected during later visits, especially in 2015 and 2018. The study thus represents two decades of observations of tradition and change in the region.

\section{Shrines, saints and pilgrimage in Islam}

The interplay between the stable and fluid elements of the religion is displayed in the tradition of saints, shrines and tombs in Islam. While many of the holy sites are local in nature, the most important saints attract pilgrims on a global scale. Architecturally, the buildings range from simple structures to large complexes.

Though usually translated as saint, the word wali has several meanings, among them $a$ friend, a protector or a benefactor. Wali Allah refers to a person who is close to God, and thus blessed with characteristics and abilities that surpass the limits of normal mortals: piety, generosity, wisdom, knowledge of God's law - even supernatural abilities, such as teleportation or acute hearing (Taylor 1998a: 112). While still alive, such a man (or woman) becomes an object of emulation and reverence, providing a role model and a living example of how to live according to the Sacred Law. Being closer to God, they are able to act as intercessors, making the prayers more easily heard by God. After the death of a holy person, the people continue to visit the tomb, believing in the saint's continuing ability to act as a mediary, and attempting to acquire the saint's baraka, a benevolent power which radiates from the holy place. In Arabic, this practice is called ziyara ('visit'), referring specifically to the act of visiting graves (ibid. 109), and in this sense differing from the great Islamic ritual pilgrimages, hajj and 'umra. Nevertheless, ziyara is generally translated as 'pilgrimage'.

Pilgrimages to shrines and tombs have been a topic of scholarly discourse throughout the history of Islam. Many scholars, including Ibn Taymiyya (1263-1328), and his pupil ibn Qayyim (1292-1350) condemned the ziyara tradition. Their ideas are also dominant in current Salafi thought.

However, making a distinction between 'scholarly Islam' and popular beliefs is an oversimplification, the reality being much more diverse and complex. Even Ibn Taymiyya, though attacking the prevailing practice, also identifies a lawful ziyara. Visiting the tombs was not banned as such, since they remind the visitor of the hereafter and of the shortness of life. It is the tombs becoming a sole object of travel and veneration that should be strictly condemned (Taylor 1998b: 205). The importance of Sufi orders in promoting and preserving the pilgrimage tradition has been discussed by Taylor (ibid. 70), who relates the rise of the cult of saints to the developing Sufi philosophy and the Sufi orders, which organized weekly visits and larger annual celebrations.

The emergence of reformist Islamic thought in the 1970 s has had a significant effect not only on the Muslim religious debate, but also on other social arenas (Mahmood 2005; Schielke 2012: 132-3). Schielke (2008) has observed the currents in Egypt, with new demands for piety, morality and the use of public space changing the traditions of saints and their festivals among the local communities. Similar processes can also be observed in Jordan. In today's Jordan, the Ministry of Awqaf plays a major role in reconstructing, maintaining and promoting the religious sites that have a connection to Quranic tradition or Islamic history.

\section{Southern Jordan: geography and sacred topography}

In this context, Southern Jordan does not denote any specific geographical entity, as it consists of four different north-south running regions, all extending beyond the area of this study. In the west, the low and flat Wadi Araba runs from the Dead Sea in the north to the Red Sea in the south. The elevation rises drastically towards the east, forming a rugged escarpment, rising higher into a mountainous belt further 
east until the terrain becomes more level and forms the western end of the vast Syro-Arabian steppe. I use 'Southern Jordan' to discuss the area of my empirical study, extending south of Tafila and west of the Ottoman-period Hajj route.

Until the twentieth century, the population of the region consisted mostly of nomadic and semisedentary tribes, Ma'an and Aqaba being the major settlements. Direct state rule was not fully imposed on the local population until the Mandate period, but the region was not isolated earlier either: the pilgrimage route from Istanbul to Mecca was an important pathway, and the Ottoman state invested large sums of money - by paying tribute to local tribes and by establishing military strongholds - to secure safe passage to travellers. The town of Ma'an was the last of the resting stations before the pilgrims continued their way across the Hijaz. The town attracted farmers and pastoralists selling their products to the pilgrims, pilgrim guides, and other entrepreneurs. The tribal networks were also extensive - both in peace and war.
Today, several smaller settlements, many of them only recently built by the government for the tribes, lie scattered throughout the region. Governance structures have been established along with an increasing effort to sedentarize the population. In recent decades, the traditional boundaries between people living in towns and villages and the nomadic communities have become more fluid, with the nomadic and semi-nomadic tribal populations being increasingly sedentarized and seeking new sources of income, including waged labour and tourism. While tribalism and Bedouin-ness continue to play an important role as social identities and cultural markers, people have had to adapt to new influences and increased state control. The state-administered teaching curriculum and religious education provides a relatively homogeneous system throughout the country. The effects of social and economic changes extend to all fields of life, including religious beliefs and women's roles in the society.

In the region the majority of holy sites are the tombs of tribal ancestors, regularly visited by the

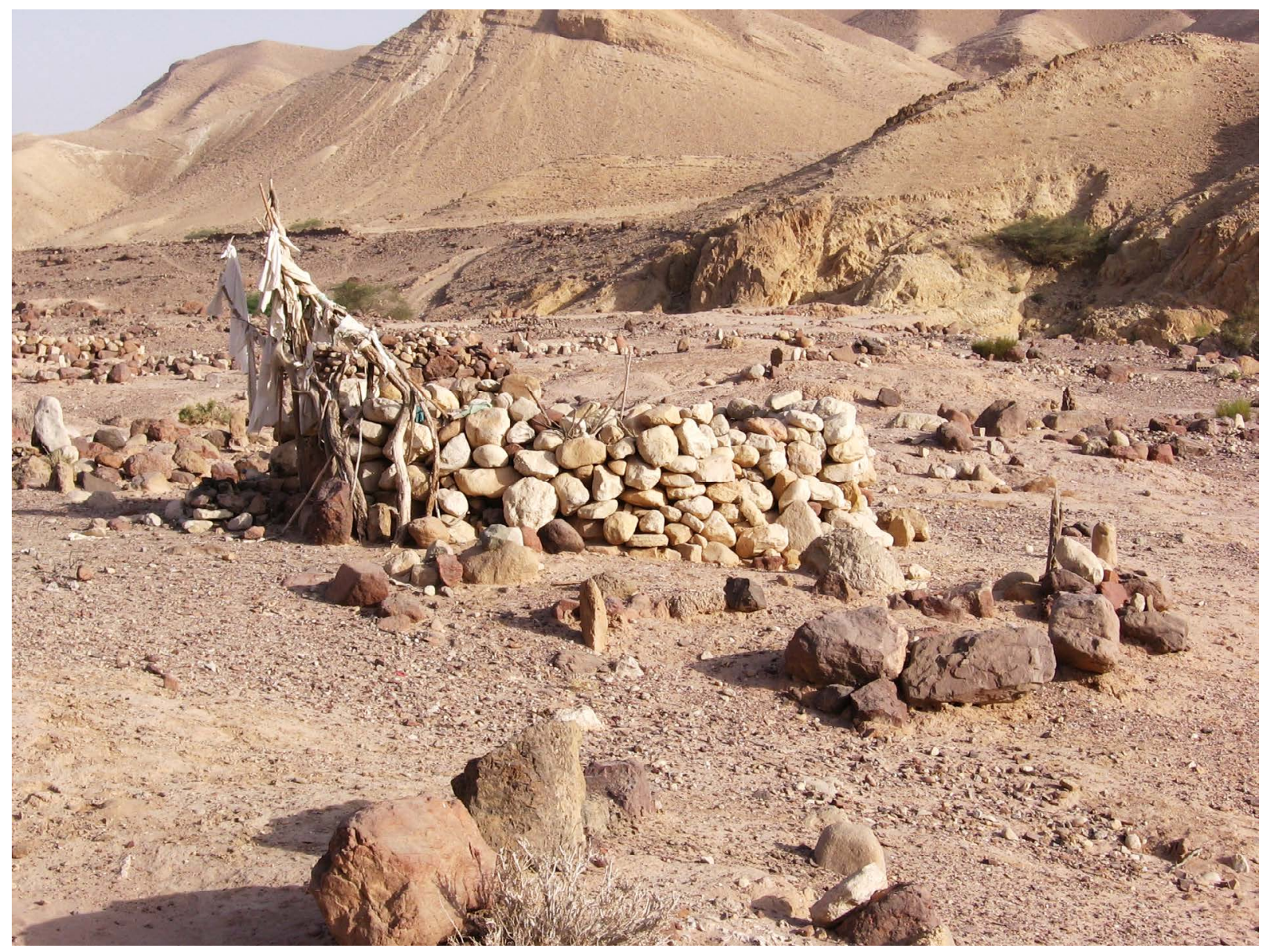

Tombs of the ancestors of the 'Ammarin tribe near Bir Madhkur in Wadi Araba. Photo: Päivi Miettunen. 


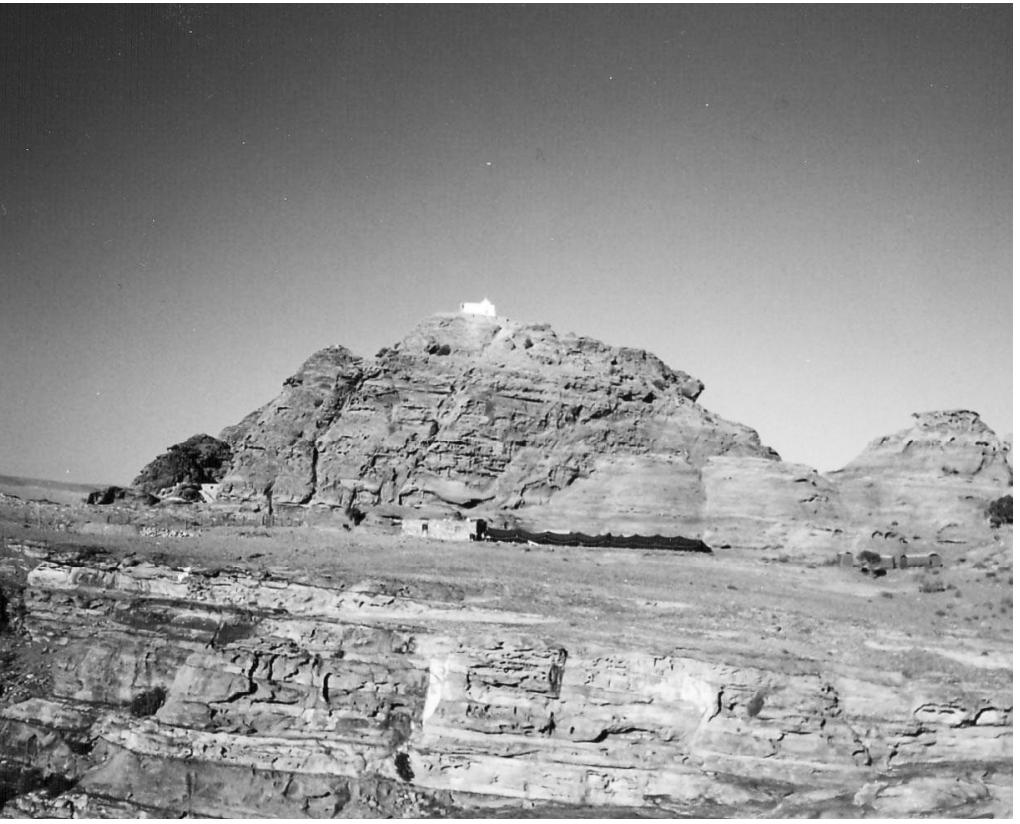

Aaron's shrine. Photo: Päivi Miettunen.

descendants of these leaders. However, the most prominent holy site is the shrine of Harun, the biblical Aaron. The mountain is the highest in the rugged escarpment facing Wadi Araba, rising to 1,327 metres above sea level. At the very top of the mountain the whitewashed shrine is easily visible from all directions. The Nabataeans, who established a large trading empire with the city of Petra as the capital, already considered the mountain to be sacred. Antti Lahelma and Zbigniew Fiema (2009) suggest that a sanctuary dedicated to the goddess al-'Uzza was once located on the mountain. Later, a Byzantine church dedicated to the high priest Aaron was built at the top of the mountain, along with a pilgrimage centre built on the high mountain plateau. During the fourteenth century, the church was replaced by an Islamic shrine, while the complex on the plateau was abandoned.

The shrine is a small, approximately $10 \times 8$ metre whitewashed stone building with a semi-circular dome. Inside the vaulted room a cenotaph stands next to the entrance. It is a small, approximately $\mathbf{1 . 2}$ metre long plastered stone structure. On the northern wall, a round obsidian plate, approximately $25 \mathrm{~cm}$ in diameter, has been attached to the wall. According to the informants, the visitors press their heads against the stone and kiss it. There is also a low platform for burning incense and candles. Underneath the platform, a stairway leads down to an underground grotto. The grotto contains a narrow vault which ends in a plastered wall and a small niche.
When looking at women's opportunities for pilgrimage, the locations of the holy sites can be very significant. Located on a mountaintop, the shrine of Aaron is relatively hard to reach. The journey is demanding both physically, and in terms of time. Only a few of the holy sites in the region are situated inside a village or town: three sites still exist in the town of Wadi Musa, and four are known in Ma'an. The most famous of them, Umm Jadi', is dedicated to a female saint, whose holy place was a peculiarlooking stone formation protruding from the side of a wadi. The majority of the sites, however, can be found in a desolate area, far from any settlement. It should be noted though, that the settlement patterns have changed as pastoral cycles have discontinued. In the past, the locations may have been more relevant for the tribes. Some of them are found near water sources, for example, the ancestral tombs of 'Iyal Awwad are in the vicinity of Bir Madhkur, an important well in Wadi Araba. The tombs of Al-Bawwat, or al-Fugara ${ }^{2}$, lie next to 'Ayn Amun, a perennial spring. This site is not connected to any tribe of the Petra region - the 'poor' (fugara) were said by the locals to be a group of holy men from the Jordan Valley. Finally, the graves of Sabbah, Ahmad and Ghannam, ancestors of the Saidiyin tribe, are located near the well of Bir Hamad. These locations could offer a natural opportunity for visiting holy sites, as fetching water is a daily task for women.

\section{Communal pilgrimage and the role of women}

For the Liyathne tribe of Wadi Musa and Tayybe, the most important annual event was the pilgrimage to Jabal Harun and the subsequent festival. The celebration took place at the beginning of the rainy season during the early autumn or late summer. Compared to a wedding party, the festival consisted of singing, dancing, shooting, ululation, races and festival meals. The annual visit was formally declared by the leaders, but the preparations started long before the celebration. For women this meant an additional workload, including cooking and preparing new clothes for the whole family. Plenty of food was needed, as during the festivities, all relatives, friends, and poor people were invited to attend the meals. On the first day of the festival, a procession of people made their way

2 The pronounciation of 'qaf' as 'gaf' is a typical element in many Bedouin dialects. 
to the mountain to spend the night on the mountain plateau. Women participated in the pilgrimage along with the men and would also spend the night on the mountain. On the second morning they visited the shrine, singing and praying inside the small building. When visiting the shrine, the men would go first, after which the women formed a second group. After a meal on the mountain the people descended and returned home. During the afternoon horse races were held, also attracting people who did not visit the mountain to attend the celebrations in the villages. In the evening, a large feast was prepared. This meal was known as the 'Dinner of the Prophet Aaron', and the goats to be slaughtered for the meal would have been chosen in the early spring. These newborn kids were dedicated to the prophet, and a mark was cut into their ear as a sign of this.

Some individuals from other tribes were mentioned as having joined the annual pilgrimage of the Liyathne. The Bedul tribe of Petra and the neighbouring Ammarin tribe could organize a tribal visit to Jabal Harun if the rains did not begin, and the drought threatened the wellbeing of animals and people. Their procession to the mountain was a solemn one. Only upon returning would they make expressions of joy. Instead of competing with horses, camel races could be organized after the visit. Killing a goat as a sacrifice and sharing a meal with other families at the night after the visit has also been part of this tradition.

In addition to Jabal Harun, communal pilgrimages were also organized to other local sites. The women of Wadi Musa organized their own pilgrimage to al-Bawwat (Al-Salameen and Falahat 2009: 189). A large annual pilgrimage was also mentioned in connection to the cemetery at Bir Hamad. The site was visited by the members of the Sa'idiyin tribe, who also camped near the well during their pastoral cycle. The Ammarin had their own annual pilgrimage to the cemetery of 'Iyal Awwad. These annual celebrations were also social gatherings. As the families of the nomadic tribes could be separated for the most part of the year, the annual pilgrimage brought all the members of the tribe together.

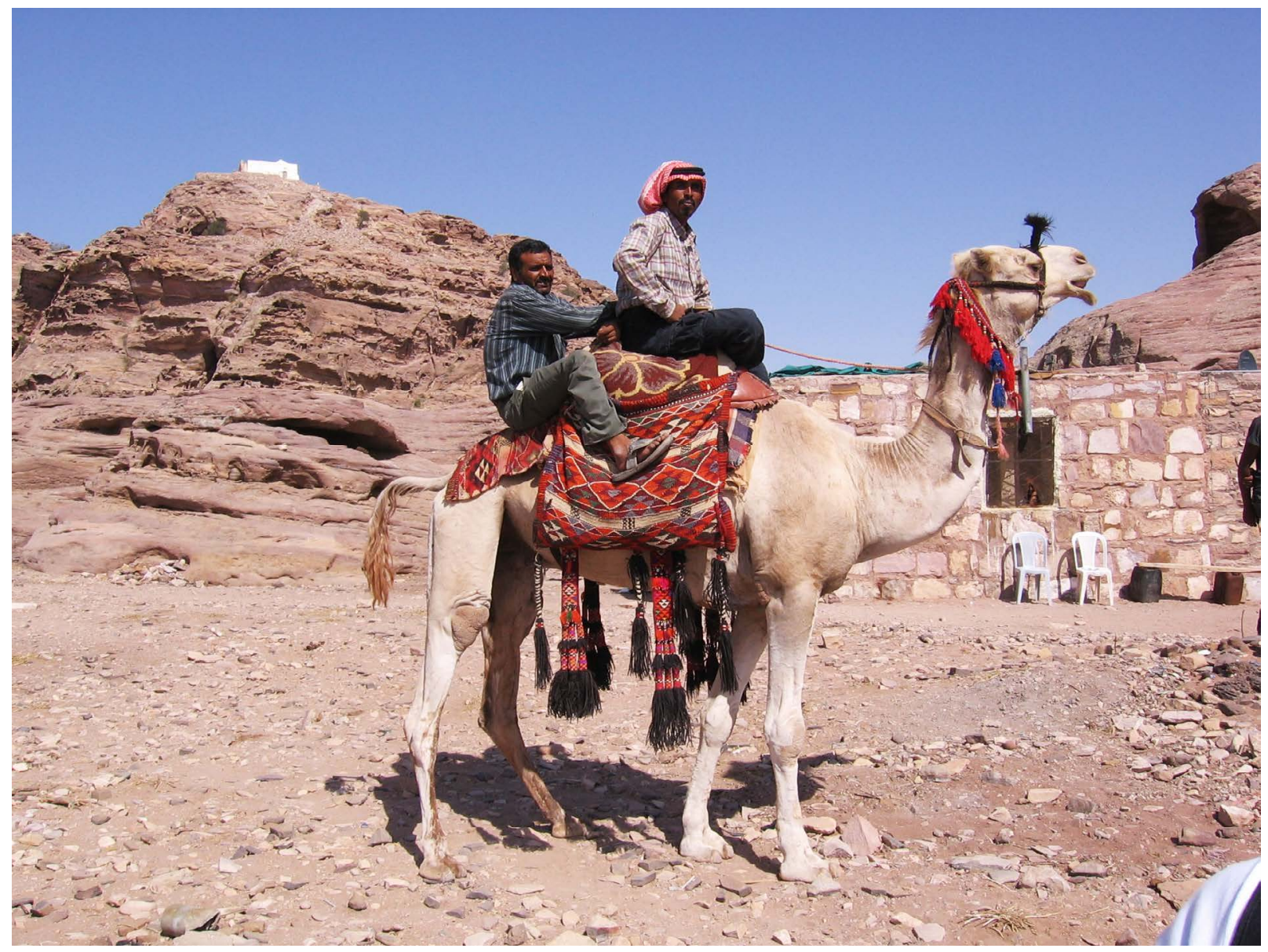

A Bedul Bedouin with his camel. Aaron's shrine can be seen at the top left corner. Photo: Päivi Miettunen. 
While visiting Harun's shrine has been the major ritual action for the provision of rain, there have also been others. One such rain procession is documented in several records pertaining to an area reaching from Morocco to Turkey and Iran (AbuZahra 1988; Başgöz 1967, 2007). In the Middle East, including Southern Jordan, the ritual was known as 'The Mother of Rain' (Umm al-Ghayth). In Wadi Musa the ritual was initiated and conducted by the women. A doll was constructed from branches, or a ladle, broom or some other frame, and clothed. This doll was then carried around as part of a procession. The participants visited homes, singing and asking for food. At the end, the donated food was cooked and eaten. Several songs relating to the Rain Mother ritual have been published (Musil 1928: 10-13; Musil 1908: 8-10; Jaussen 1948: 323-9; Canaan 1926: 14453, Westermarck 1926: 268-9; Başgöz 1967: 304-6). In 2007, I recorded the following example in $\mathrm{Ma}$ 'an, Jordan:
Yã umm-al-ghayth ghaythīnā
Ballī shwayshet rāànā
Rāīnā Hasan al-Qarāē
Lā bōkul wa-lā bishba
Ghayr al-dūde al-dūde al-dūd
Wa-l- 'așal 'indo mamdūd
O Mother of the Rain, rain upon us
Wet the head of our shepherd
Our shepherd is Hasan al-Qara
He does not eat nor is he sated
Except the worm, the worm, the worm
And he has plenty of honey.

The lyrics follow a typical pattern: the singers address the Rain Mother, asking for rain and giving concrete examples about how the lack of water affects them. In this case the lyrics mention the shepherd of the tribe. Contrasting his situation with a lowly worm the singers beg the Mother of Rain to share the blessing of water and abundance also with the people.

In most places the Rain Mother procession was a separate ritual. However, in the Petra region the procession seems to have always been connected to Aaron's shrine. In earlier times, the women would stop at a location in Wadi Musa facing Aaron's shrine to recite the songs. Later, the songs for Umm al-Ghayth were recited by the women during the autumn pilgrimage on the mountain, even inside the shrine itself. Performing the ritual provided these women with a specific role during the larger celebration.

Jan Berry (2006) challenges the notion of communitas on pilgrimage, stating that it does not equally represent the experience of the two genders. Firstly, in many communities, the women cannot fully detach themselves from their domestic duties. Even during the pilgrimage - and especially in connection to the celebrations connected to the pilgrimage season - the women continue to be responsible for day-to-day tasks such as cooking, cleaning and childcare. Based on this fact, Berry (ibid. 277) argues, the women's 'spiritual journey' does not take them very far from the domestic sphere.

In the case of the annual pilgrimage to Aaron's Mountain, the women did have much work to do in addition to their daily tasks. But the chores that Berry described as inhibiting the communitas, appear in the narratives of local women as things which were positively expected and anticipated. Having a chance to enjoy a good meal and receive new clothes had no implication or sense of a burden. The pilgrimage is a mixture of secular festivities and spiritual experience, and the preparations for the celebration form an important part of the women's communal experience.

\section{Women and the private pilgrimage}

Both communal and private pilgrimages were occasions where personal needs could be expressed. Throughout the year, individuals, families and small groups of people could visit any of the sites, although on many of the smaller sites the visitors were mostly descendants of the ancestor buried on site. Thursday was the most favourable day, but visits were not restricted to one day only. People could make a day visit or spend a night at the holy place.

The personal pleas included prayers for a cure for an illness or protection against witchcraft, praying for fertility (of both people and animals), wellbeing and good fortune. The wali was also believed to protect the people and their property, and animals and personal belongings could be left at the shrine or tomb for safekeeping. It was also a common tradition in the region that a newborn child would be taken to the shrine. The person doing this was preferably the mother, but if she was too weak, any other member of the family could take the baby and introduce them to the saint or the ancestor. This took place before the child was shown to any other (living) members 
of the family. For greater protection, the child could be named after the saint. The protective power of the saint could also be extended to children by 'binding' 3 the child to the saint:

My brother Saleh was bound to Prophet Harun. My mother gave birth to me and then maybe 18 years passed when she did not conceive - it finished: she did not get more children, there was only [one son] 'Abbas. But, finally, after 18 years she became pregnant. She was already an old woman and her head was totally white. So, she gave birth to Saleh and she was very delighted, by the face of God. But since her breasts did not produce milk anymore the wife of 'Abbas nursed him. And she [the mother] declared: 'By God, today God has given me this boy. Tomorrow I die, and they read the Quran by my head. And I bind you to Prophet Harun.' Anyway, she gave birth to Saleh and they visited Prophet Harun until she died, God have mercy upon her, and after her death Saleh - shame on him - probably he did not visit the Prophet Harun anymore. (Woman from Wadi Musa 2002)

The importance of a large family, especially sons, among the Bedouin, is reflected in this story, and in many other stories that discuss infertility and seeking help from the saint. As blame would fall mostly on the women, it would be they who also often went seeking for help from the holy sites. Antonin Jaussen (1907: 303) explains, how in Ma'an, women suffering from infertility would visit Umm Jadi', and '... rest in the shadow and rub her body against the stone or with the soil taken from the foot of the rock. She returns to her home with the firm belief that she will be a mother soon. However, Umm Jadi“ was not only visited for benevolent goals: a woman who was unhappy in her marriage could visit Umm Jadi', brush the surface of the stone clean, and beg the saint to take away her husband (Man from Máan 2007).

The tradition of visiting saints among the tribal people of Southern Jordan seems to differ slightly across rural and urban settings. Fatima Mernissi (1977: 105) claims that for the women in towns and villages, visiting shrines was not a religious act at all. Instead, it formed a safe space, and a 'therapeutic net- work of communication', offering the women 'a community of supporters, soothers and advisors'. During the public pilgrimage, the women were often strictly controlled by the family members who feared that they might have contact with strangers during the celebrations. The suspicions and controlling attitudes are reflected in the scholarly texts, expressing deep concern over the improper behaviour and promiscuity of women in the public gatherings and pilgrimage (Andezian 1997: 193; Cuffel 2005: 402; Greenberg 2007: 7; Shoshan 1991: 92-3).

Possibly partly due to the suspicions, and the risk of gaining a reputation for promiscuity when participating in pilgrimage in a mixed company, women started arranging their own rituals. ${ }^{4}$ The Rain Mother ritual of the Petra region could be seen as such a ritual; belonging to a larger pilgrimage, yet set apart and reserved for women. While singing and dancing was frequently mentioned by the Bedouin informants as being part of the pilgrimage and the subsequent celebrations, the women's behaviour was not criticized as such. In addition, while the Bedouin women enjoyed the annual festivals and other social occasions of the community, the private pilgrimage appears to have been a more solemn and solitary by character.

From the men's point of view, the women's rituals may appear to be a mere 'by-product', and not part of the official ritual. For the women, however, it is very much part of their ritual experience - for some, it is the main event. Thus, calling it a marginal ritual would be disregarding the women's experience (Andezian 1997: 205).

\section{Shifting sentiments}

Visits to the shrines have been made by both genders, of all ages and all social classes, yet the local pilgrimage has at times been labelled as specifically the women's religious activity, connected to their (religious) ignorance, and emotional nature (Shoshan 1991: 83; De Jong 1976: 26; Marcus 1985: 457). Although the men, too, could - and did - show emotion, the writings mostly ignore these expressions. The power of women's emotion is evident in the tribal context, where the wailing and mourning of women on the graves of the dead (especially in the

4 See e.g. Andezian (1997) on an Algerian women's vigil, and Hegland (2003) on the private Muharram gatherings of the Pakistani women. 


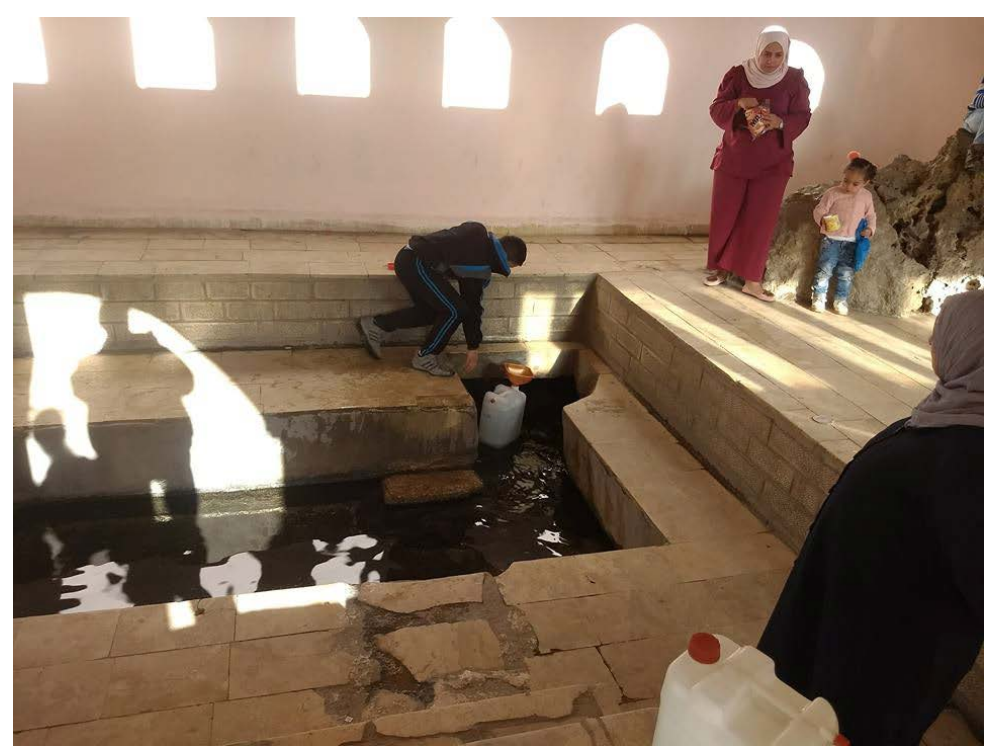

The Spring of Moses in Wadi Musa. Photo: Janne Hägglund.

case of a violent death) could incite blood revenge and civil unrest, and thus represented dangerous political agency (Greenberg 2007: 12). On the other hand, excessive crying was also seen as a form of protest against God's will (ibid. 4). Today, the women in Petra region do not participate in the funeral ceremony. In fact, many do not even enter a graveyard in any situation. They also resent showing emotions while mourning, referring to the necessity of accepting God's will.

Current public opinion is mostly against visiting the holy sites, which are often declared to be pagan and un-Islamic. Even the annual pilgrimage to Jabal Harun has been forbidden by the religious authorities, although the shrine itself - being the tomb of an Islamic prophet - is moderately tolerated. People refer to the Hadiths, stating that there are only three places to which pilgrimage is acceptable: Mecca, alAqsa in Jerusalem, and the Prophet's tomb in Medina.

Apparently, however, not all people in the region have accepted this situation and some insist on continuing the visits. In Southern Jordan, the most devout visitors to holy sites were said to be the older women who had made an oath to visit the wali every year until they die. The Bedouin women rarely travelled long distances in large groups for social reasons, but the possibility of visiting the shrines and graves brought variety to everyday life routines. The mothers who had bound their children to the saint, often made an oath to visit the holy site every year.

Over the past two decades, I have noticed a grow- ing tendency among the people to distance themselves from certain elements of the tribal past. Especially the young women have expressed their awareness of outsiders seeing them as ignorant and primitive pagans. They want to prove that whilst they are still Bedouin, they can also be modern and educated Muslims. This includes solidifying and embracing new structures in the community, both secular and religious. Of the secular structures, the education of girls has quickly risen to become an important element in the society. ${ }^{5}$ In Petra, I spoke with two women who had been the first female students to attend the local school in the 1970s. They had had to struggle against general opinion which did not see educating girls as being useful, and both had eventually studied for only a couple of years before quitting. Today, the majority of girls have access to a basic education, and they increasingly continue their studies in universities and colleges. While the number of women in the workforce is still low, education is seen as an asset in the community, and provides a higher status in marriage. In 2018 , informants in the northern village of Zaatari made a comparative reference to Syrian refugees of tribal background, saying that unlike the Jordanians they don't educate their women,

Of the religious structures, the importance of local holy sites and the practices related to these sites has diminished. On the other hand, pilgrimage to Mecca has become more common. In 2018, I discussed the topic with a Bedouin woman in the Petra region. Since reaching the age of 40 , she had performed 'umra four times with her mother, travelling to Saudi Arabia in a group of five or six women, without a male guardian. William Young (1993: 286) also mentions, how elite Saudi women have gained

5 Lila Abu-Lughod (1990) observes the secular changes among the Awlad 'Ali Bedouins in Egypt, brought by modernization, sedentarization and a capital-based economy. While she describes the increased control and restrictions imposed on women, the modern life also puts more pressure on men, who must be able to offer a furnished house, clothing and sustained maintenance before they can expect to find a wife. I have observed similar transformations taking place in Jordan during the past 20 years. 
more freedom to make the hajj without close male relatives accompanying them. For my informant, however, the same freedom was based on her age, not on her social status. She was also anticipating the possibility of performing hajj, but for this she would have to wait until she reached the age of 60 - an age limit set by Jordanian religious authorities, possibly due to the large number of people wishing to perform the pilgrimage. At the same time, it should be kept in mind that the pilgrimage has largely been enabled by the current structure. In the past, a trip that took months to complete, the dangers on the journey, and merely the cost of the expedition made the pilgrimage largely impossible for the majority of people, especially for women.

\section{Conclusions}

The foregoing narratives show examples of the interplay between the three temporal dimensions presented by Emirbayer and Mische: past routines, present engagement and future aspirations. Earlier, the religious practices appear to have had a relatively short-term future trajectory. For example, the opening narrative describes how the woman uses her agency in finding a solution to her current condition (having lost her voice). Thus, by iterating her experiences of the past actions, and using the examples of how she could be cured, she chooses a present action as an attempt to change her condition - by visiting the tomb of the saint. Naturally an aspiration for the future, that of being healthy again, is also present in this action, but her main focus is to return to the condition that was prevailing earlier - before she lost her voice - and not make any further changes in her life. Similar examples of using the roles provided by the structure to find solutions to present conditions can be found in other narratives. Securing protection against theft or witchcraft, seeking a cure for illness and infertility, or praying for rain are all religious activities where the women have shown agency parallel to men's - and in the case of the 'Mother of Rain', they have also been the leaders of the ritual.

With the emergence of new forms of religious thinking transforming the prevailing structure, many roles of the past have become less accepted in the region. While many still have memories of visiting the saints, these past actions can no longer be used as models for present action. Increasingly, it seems, the projection has shifted towards a much more long-term future perspective. For example, while a pilgrimage to Mecca does bestow an individual with the respected status of a 'Hajj(e)', it is not an action that greatly changes the present. On the contrary: the trip can place an economic strain on women living in poor conditions, thus at worst adding to the uncertainty of their current life, when money is not saved but used for travelling. The pilgrimage is one of the pillars of Islam, and thus as an action it is heavily rooted in the past. At the same time, it is anchored in the future. Living as a good Muslim and abiding to the tenets of Islam is a path that leads to Paradise in the life to come.

Some of the older women exhibit the agency of resistance by insisting on continuing the old pilgrimage traditions. They refer to a local proverb: 'create a tradition, but don't cut a tradition'. While understanding that things change, they also want to maintain the old ways. The women who denounce the old tribal traditions are also exercising agency - even when it seems to be limiting the religious roles available to them. Their choices are made in the name of preserving their identity and choosing how it is being defined. They refuse to accept the derogatory definitions of being Bedouin which are applied from outside. Instead, they want to define it in their own terms. While their actions continue to be embedded in the structure, they have been - and continue to be - the agents that also change the structure.

\section{Dr Päivi Miettunen holds a} $\mathrm{PhD}$ in Middle Eastern studies from the University of Helsinki. Currently, she lives in Beirut and works as a researcher and coordinator in the Finnish Institute in the Middle East. Her postdoctoral research project focuses on information practices and identity building in tribal communities. In 2016, she worked as a visiting researcher at the Centre for Middle Eastern Studies in Lund University, focusing especially on information sharing and representations of tribal identities in social media. Her doctoral dissertation was a case study of holy sites in Southern Jordan. Miettunen spent several months among the Bedouin in the region, collecting data about the various sites and observing their social and religious functions. This project was a direct continuation from her MA thesis, in which she focused on the site of Aaron's Mountain near Petra. Miettunen was a member of the Finnish Jabal Haroun Project between 2000-7. Through her 
ethnographic research, Miettunen has gained extensive knowledge of Jordanian society and tribal communities. She is interested in the processes of community engagement through information sharing and collaboration.

\section{References}

Archive sources

Personal field diary and recorded interviews from Jordan 2002, 2005, 2007, 2011, 2015, 2018.

\section{Literature}

Abu-Lughod, Lila, 1990. 'The romance of resistance: tracing transformations of power through Bedouin women', American Ethnologist, 17(1), pp. 41-55

Abu-Zahra, Nadia, 1988. 'The rain rituals as rites of spiritual passage', International Journal of Middle East Studies, 20(4), pp. 507-29

Ahearn, Laura, 200o. 'Agency', Journal of Linguistic Anthropology, 9(1-2), pp. 12-15

Al-Salameen, Ziyad, and Hani Falahat, 2009. 'Religious practices and beliefs in Wadi Mousa between the late 19th and early 2oth centuries', Jordan Journal for History and Archaeology, 3(3), pp. 175-204

Andezian, Sossie, 1997. 'The role of Sufi women in an Algerian pilgrimage ritual', African Islam and Islam in Africa: Encounters between Sufis and Islamists, ed. E. E. Rosander and D. Westerlund (London, Hurst\&Company), pp. 193-215

Başgöz, Ilhan, 1967. 'Rain-making ceremonies in Turkey and seasonal festivals', Journal of the American Oriental Society, 87(3), pp. 304-6

- 2007. 'Rain making ceremonies in Iran', Iranian Studies, 40(3), pp. 385-403

Berry, Jan, 2006. 'Whose threshold? Women's strategies of ritualization', Feminist Theology, 14(3), pp. 273-88

Canaan, Tawfiq, 1926. 'Mohammedan saints and sanctuaries in Palestine', Journal of the Palestine Oriental Society, 6, pp. 1-69, 117-58

Cuffel, Alexandra, 2005. 'From practice to polemic: shared saints and festivals as "women's religion" in the Medieval Mediterranean', Bulletin of the School of Oriental and African Studies, 68(3), pp. 401-19

De Jong F., 1976. 'Cairene ziyâra-days: a contribution to the study of saint veneration in Islam', Die Welt des Islams, New Series, 17(1), pp. 26-43

Emirbayer, Mustafa, and Ann Mische, 1998. 'What is agency?', The American Journal of Sociology, 103(4), pp. $962-1023$

Geldermalsen, Marguerite van, 2009. Married to a Bedouin (London, Virago Press)

Giddens, Anthony, 1984. The Constitution of Society: Outline of the Theory of Structuration (Berkeley, University of California Press)

Greenberg, Dina, 2007. 'Gendered expressions of grief: an Islamic continuum', Journal of Religion \& Society, 9, pp. $1-20$

Gulati, Ranjay, and Sameer B. Srivastava, 2014. 'Bringing agency back into network research: constrained agency and network action', Contemporary Perspectives on Organizational Social Networks, ed. Daniel J. Brass, Giuseppe Labianca, Ajay Mehra, Daniel S. Halgin and Stephen P. Borgatti, Research in the Sociology of Organizations, 40 (Bingley, Emerald Group), pp.73-93

Hegland, Mary, 2003. 'Shi'a women's rituals in Northwest Pakistan: the shortcomings and significance of resistance', Anthropological Quarterly, 76(3), pp. 411-42

Hitlin, Steven, and Monica Kirkpatrick Johnson, 2015. 'Reconceptualizing agency within the life course: the power of looking ahead', American Journal of Sociology, 120(5), pp. 1429-72

Jaussen, Antonin, 1948. Coutumes des Arabes au pays de Moab (Paris, Adrien-Maisonneuve)

Korteweg, Anna, 2008. 'The Sharia debate in Ontario: gender, Islam, and representations of Muslim women's agency', Gender and Society, 22(4), pp. 434-54

Kristiansen, Marcus, 2014. Agency as an Empirical Concept: An Assessment of Theory and Operationalization, Netherlands Interdisciplinary Demographic Institute Working Paper no. 2014/9, <https:// www.nidi.nl/shared/content/output/papers/ nidi-wp-2014-09.pdf> (accessed 29.9.2018)

Kupari, Helena, 2016. Lifelong Religion as Habitus: Religious Practice among Displaced Karelian Orthodox Women in Finland (Leiden, Brill)

Lahelma, Antti, and Zbigniew Fiema, 2009. 'From goddess to prophet: 2000 years of continuity on the Mountain of Aaron near Petra, Jordan', Temenos, 44(2), pp. 181-222

Leming, Laura, 2007. 'What is religious agency?', The Sociological Quarterly, 48(1), pp. 73-92

Mahmood, Saba, 2001. 'Feminist theory, embodiment, and the docile agent: some reflections on the Egyptian Islamic revival', Cultural Anthropology, 16(2), pp. 202-36

- 2005. The Politics of Piety: The Islamic Revival and the Feminist Subject (Princeton University Press)

Marcus, Michael, 1985. 'The saint has been stolen: sanctity and social change in a tribe of Eastern Morocco, American Ethnologist, 12(3), pp. 454-67

Mernissi, Fatima, 1977. 'Women, saints, and sanctuaries', Signs, 3(1), pp. 101-12

Musil, Alois, 1908. Arabia Petraea, vol. III, Ethnologischer reisebericht (Vienna, Kaiserliche Akademie der Wissenschaften)

- - 1928. The Manners and Customs of the Rwala Bedouin (Prague, The American Geographical Society)

O'Brien, John, 2015. 'Individualism as a discursive strategy of action: autonomy, agency, and reflexivity among religious Americans', Sociological Theory, 33(2), pp. 173-99

Porpora, Douglas, 2015. Reconstructing Sociology: The Critical Realist Approach (Cambridge University Press)

Schielke, Samuli, 2008. 'Policing ambiguity: Muslim 
saints-day festivals and the moral geography of public space in Egypt', American Ethnologist, 35(4), pp. 539-52'

- 2012. 'Capitalist ethics and the spirit of Islamization in Egypt', Ordinary Lives and Grand Schemes: An Anthropology of Everyday Religion, ed. Samuli Schielke and Liza Debevec (New York, Berghahn), pp. 131-45

Shoshan, Boaz, 1991. 'High culture and popular culture in Medieval Islam', Studia Islamica, 73, pp. 67-107

Stauth, Georg, and Samuli Schielke (eds), 2008. Dimensions of Locality: Muslim Saints, their Place and Space, Yearbook of the Sociology of Islam, 8 (Bielefeld, Transcript Verlag)

Svärd, Saana, 2013. 'Female agency and authorship in Mesopotamian texts', Kaskal, 10, pp. 269-80

Taylor, Christopher, 1998a. 'Saints, ziyāra, qișșa, and the social construction of moral imagination in late Medieval Egypt', Studia Islamica, 88, pp. 103-20

- - 1998b. In the Vicinity of the Righteous: Ziyara and the Veneration of Muslim Saints in Late Medieval Egypt (Leiden, Brill)

Teppo, Saana, 2007. 'Agency and the Neo-Assyrian women of the palace', Studia Orientalia, 101, pp. $381-420$

Westermarck, Edward, 1926. Ritual and Belief in Morocco (London, Macmillan)

Winchester, Daniel, 2008. 'Embodying the faith: religious practice and the making of a Muslim moral habitus', Social Forces, 86(4), pp. 1753-80

Young, William, 1993. 'The Kaba, gender, and the rites of pilgrimage', International Journal of Middle East Studies, 25(2), pp. 285-300 